\title{
Analyses of Soil Copper Contents on Chaponne of Carixien Soil Series of Burgundy in France
}

\author{
Alain Bermond ${ }^{1}$, Michel Mench ${ }^{2}$, Denis Baize ${ }^{3}$, Sangdeog Augustin KIM ${ }^{4 *}$ \\ ${ }^{1}$ AgroParisTech, 16, rue Claude Bernard, 75231 Paris, cedex 05, France, Laboratoire de Chimie Analytique, Paris, Île-de- \\ France, France \\ ${ }^{2}$ Universite Bordeaux III UFR Sciences des territoires et de la communication. Pessac, Aquitaine, France; INRAE, \\ BIOGECO, F-33615 Pessac, Aquitaine, France \\ ${ }^{3}$ Institut National de la Recherche Agronomique, Paris, France \\ ${ }^{4}$ Joongbu University, Companion Animal and Animal Resources Science 201 Daehangno, Chubu-myeon, Kumsan-gun, \\ Chungcheong Nam-do 32713, Republic of Korea
}

\section{*Corresponding Author}

Sangdeog Augustin KIM

\section{Article History}

Received: 21.02.2021

Accepted: 02.03.2021

Published: 29.03.2021

\begin{abstract}
Objectives: This study was carried out for assessing total and available soil $\mathrm{Cu}$ in a Carixien soil series of a part of Burgundy, France. Method: Soil samples were collected from surface-ploughed layer in agricultural fields across the southern part of the Yonne district, Burgundy, France. The extraction time of soil $\mathrm{Cu}$ ranged from 5 minutes to 24 hours. Findings: The result on Carixien soil was Chaponne. And the trend of extraction on the Carixien soil was different from the results on Domerien soil. The $\mathrm{pH}$ value of the extracted solution increased for the Chaponne soil. For purpose of comparison it remained steady in the case of the Dubloc soil from the Domerien soil series, the copper $(\mathrm{Cu})$ absorbance through the atomic absorption spectrophotometry and its content. The $\mathrm{Cu}$ concentration in the extracted solution increased up to the $24 \mathrm{~h}$-extraction (+ around $200 \%$ ) on the basis of 5 minutes. In the case of the Dubloc soil from the Domerien soil series, the $\mathrm{Cu}$ concentration in the soil extract only slightly increased during the $24 \mathrm{~h}-\mathrm{extraction}$ period (+ around 100\%) on the basis of 5 minutes. Novelty: From these data it is considered that while Domerien soils have no 'hole' for $\mathrm{Cu}$ extraction, Chaponne soil has a 'hole' for $\mathrm{Cu}$ extraction.
\end{abstract}

Keywords: Carixien soil, copper, extraction, soil pH.

\section{INTRODUCTION}

A field case study was undertaken on a Carixien soil series across the southern part of the Yonne district, a part of Burgundy, France [1]. Thereafter, the relationships between soil weight, amount of an extracting reagent and extractable soil $\mathrm{Cu}$ from the soils in this Carixien soil series were assessed. And the absorbances of $\mathrm{Cu}$ element were determined by atomic absorption spectrophotometry [2]. The authors analysed soil Cu content during extraction. Here, we present results on total and extractable soil $\mathrm{Cu}$ in Chaponne, from the Carixien soil series, region of Burgundy in France.

\section{MATERIALS AND METHODS}

Soil samples (in triplicates) were collected on $0.3 \mathrm{~m}^{2}$ area with a spade from the $0-0.25 \mathrm{~m}$ surface-ploughed layer in fields at a site belonging to the Carixien soil series, i.e. Chaponne, southern part of the Yonne district, region of Burgundy, France [1]. Soil samples were air-dried, $2 \mathrm{~mm}$ sieved and re-homogenised. This soil sample, labelled Chaponne, was used for determining soil properties and $\mathrm{Cu}$ contents. .

The method for extracting metals from the soil samples were reported by Lebourg [3] and Ghestem [4]. The time for soil extraction varied from $0 \mathrm{~min}, 5 \mathrm{~min}, 10 \mathrm{~min}, 20 \mathrm{~min}, 30 \mathrm{~min}, 1$ hour, 5 hours, up to 24 hours. The chemical reagent for these extractions was $0.05 \mathrm{M}$ EDTA (ethylene diamine tetraacetic acid) on the form of $\mathrm{Na}_{2} \mathrm{H}_{2} \mathrm{EDTA}$. The soil

Copyright (C) 2021 The Author(s): This is an open-access article distributed under the terms of the Creative Commons Attribution 4.0 International License (CC BY-NC 4.0) which permits unrestricted use, distribution, and reproduction in any medium for non-commercial use provided the original author and source are credited. 
sample was extracted in a polyethylene bottle (volume around $50 \mathrm{~mL}$ ) with an agitator, then filtrated with a Millipore system (radius of membrane, $\varnothing=0.45 \mu \mathrm{m})$. Weighted aliquots $(10 \mathrm{~g}$ dried soil) of soil samples and $30 \mathrm{~mL}$ of the EDTA solution were used. Experiments were made in triplicates for this report; soil sampling, soil analyses, crop analyses. These two experiments of soil sampling and crop analyses were performed. The $\mathrm{Cu}$ concentrations in the extracted soil solution were determined by air-acetylene flame atomic absorption spectrophotometry (AAS) (model: VARIAN SPECTRAA 250 PLUS), and its wave length was $324.8 \mu \mathrm{m}$. Background correction was not used for Cu analysis [5].

\section{RESULTS AND DISCUSSION}

The $\mathrm{pH}$ value of the extracted solution increased for the Chaponne soil. For purpose of comparison it remained steady in the case of the Dubloc soil from the Domerien soil series (Fig.1). The $\mathrm{Cu}$ concentration in the extracted solution increased up to the $24 \mathrm{~h}$-extraction (+ around $200 \%$, Fig. 2) on the basis of 5 minutes. In the case of the Dubloc soil from the Domerien soil series, the $\mathrm{Cu}$ concentration in the soil extract only slightly increased during the $24 \mathrm{~h}$-extraction period (+ around $100 \%)$ on the basis of 5 minutes.

Table 1 shows changes in the absorbance the EDTA-extractable soil $\mathrm{Cu}$ for Chaponne. From these two Figures, it is known that Chaponne soil has a 'hole' of $\mathrm{Cu}$ extraction while there was no 'hole' on Dubloc on Domerien soil [6]. Here 'hole' indicates the possibility for detachment, so it can show us the possible extraction of $\mathrm{Cu}$ in the case long extracting time. Pinta et al. [5] wrote that there are some factors which have affect to the changes of absorbance of $\mathrm{Cu}$, for example, temperature, associated anion, interaction with other minerals.

From these data it is considered that while Domerien soils have no 'hole' for $\mathrm{Cu}$ extraction, Chaponne soil has a 'hole' for $\mathrm{Cu}$ extraction.

Table-1: Copper absorbance on atomic absorption spectrophotometry during soil extraction for Chaponne (Carixien) soil

\begin{tabular}{|c|c|c|c|c|c|c|c|c|}
\hline $\begin{array}{l}\text { extracting time (h : min : } \\
\text { sec) }\end{array}$ & 00:00 & 00:05 & 0:10:00 & 0:20:00 & 00:30:00 & 01:00:00 & 5:00:00 & 24:00:00 \\
\hline absorbance (x 0.001) & & 46 & 57 & 67 & 69 & 81 & 109 & 161 \\
\hline \multirow{7}{*}{ (on 10 nov 1998) } & & 46 & 59 & 68 & 69 & 82 & 109 & 165 \\
\hline & & 46 & 59 & 68 & 73 & 81 & 109 & 160 \\
\hline & & 45 & 58 & 67 & 70 & 81 & 107 & 154 \\
\hline & & 45 & 58 & 65 & 72 & 81 & 109 & 162 \\
\hline & & 45 & 58 & 67 & 70 & 82 & 109 & 164 \\
\hline & & 45 & 58 & 68 & 70 & 80 & 108 & 161 \\
\hline & & 45 & 58 & 68 & 71 & 80 & 108 & 157 \\
\hline mean absorbance & 0 & 45.3 & 58.1 & 67.2 & 70.5 & 81 & 108.5 & 160.5 \\
\hline standard deviation & & $\# 0.5$ & \# 0.6 & $\# 1.0$ & $\# 1.4$ & $\# 0.7$ & \# 0.7 & $\# 3.5$ \\
\hline $\mathrm{Cu}$ content (mg / $\mathrm{kg}$ soil) & 0 & 1.2 & 1.5 & 1.8 & 1.8 & 2.1 & 3 & 4.5 \\
\hline
\end{tabular}

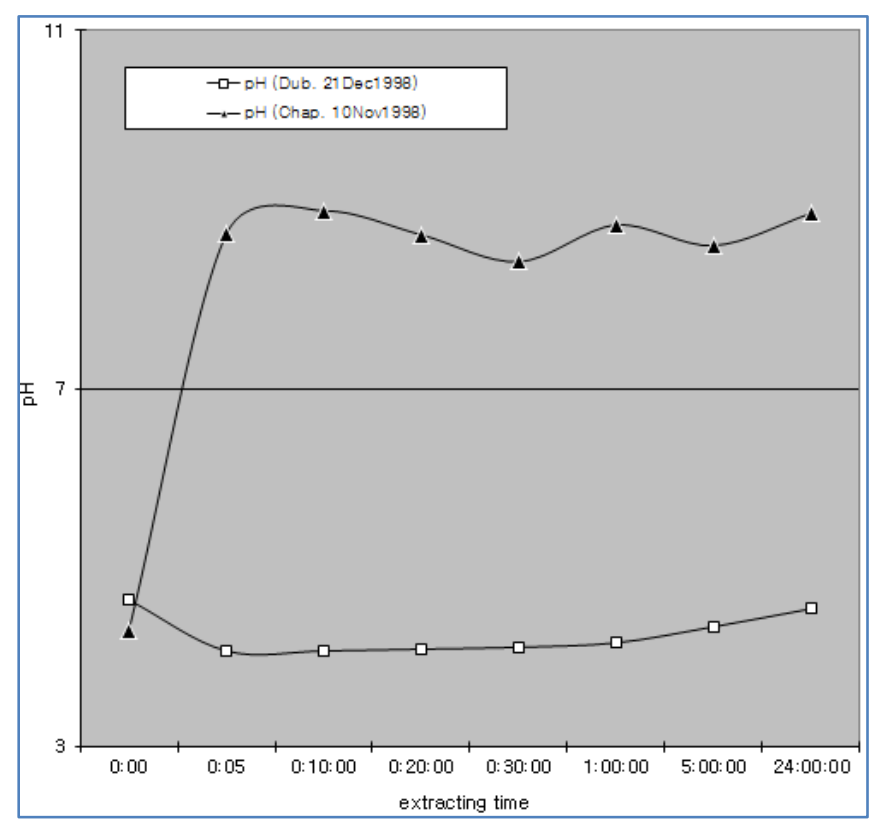

Fig-1: pH of Chaponne soil and Dubloc soil during extraction. Data of Dubloc soil was from Bermond et al. (2014) 


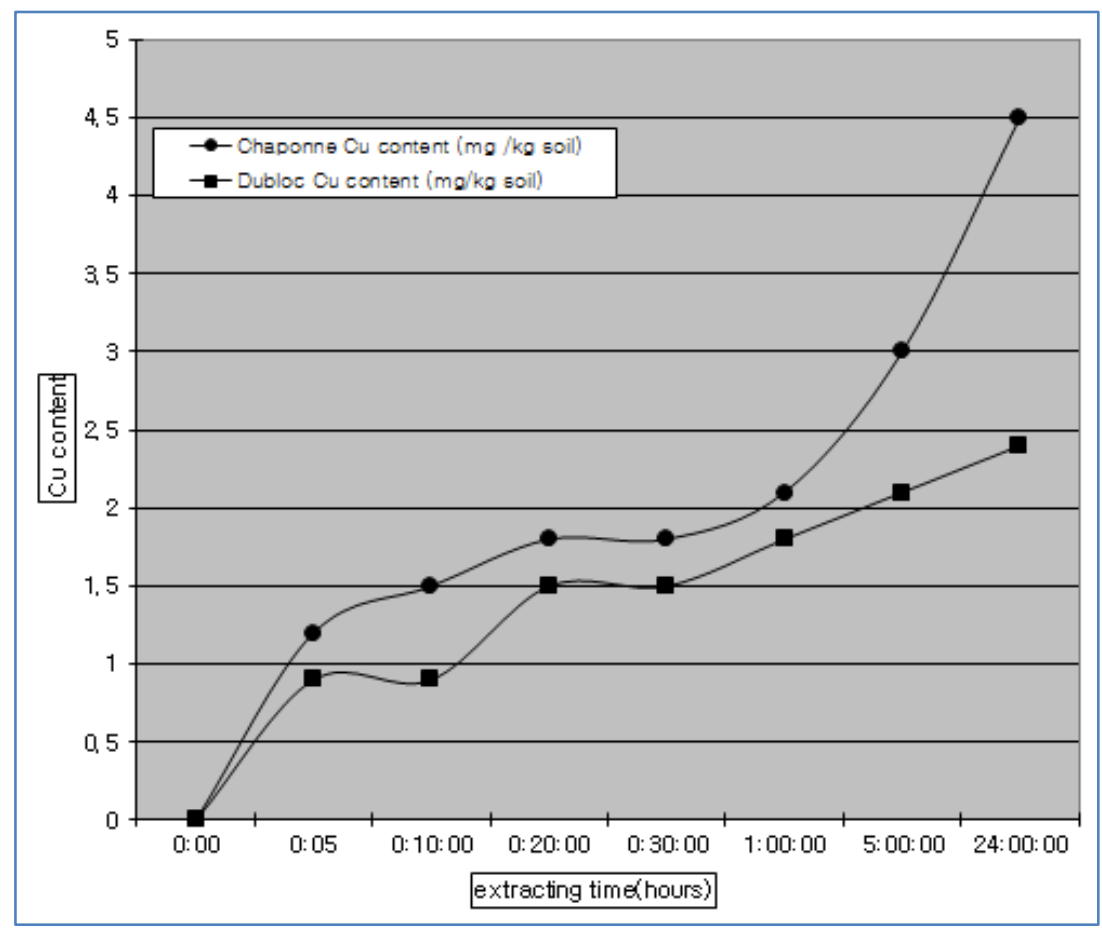

Fig-2: Comparaison of Cu content between Chaponne and Dublo. Data on Dubloc were taken from Bermond et al. (2014)

\section{ACKNOWLEDGEMENTS}

The corresponding author thanks Mr Ilsoo J. KIM and Mrs Bohwa KIM, Mr Yeonghag PARK and Mrs Hilye S. KIM, Pere Jean BLANC, Father Jeongsoo Barnabas KIM, Father Sangmin Thomas RO, Mrs Kisoon C. SONG and Mr Changyoo P. PARK, Madame Francine TENAILLON and Professor Nicolas TENAILLON, Professor Yong Kook KIM, Mr Ki Woo CHOI and Mr Jae Hong JO, Professeur C.J. DUCAUZE and Docteur Jean Claude FAVIER, Miss Og Za KIM and Mr Hwan Sik PARK, Professor Mitsuaki OHSHIMA and Professor Ryosei KAYAMA and Professor Shigekata YOSHIDA, Professor Ik Suk YUN and Professor Tae Song KOH and Professor Jae In YUN, Father Andrés S. SHIN and members of Ludovicus of Ordo Franciscanus Secularis in Daejeon in Korea, Father JungEob Paul LEE and the members of Daejeon Nae-dong Catholic Church, the student of Department of Companion Animal and Animal Resources Science in Joongbu University, Korea Water Resources Corporation, Jieun Agatha and Kunjoo Daegon-Andrea and Jiah Anna and Rosa and Sohwa Threse and his wife Hyeonhi Regina PARK.

\section{REFERENCES}

1. Mench, M., Baize D, Mocquot, B. (1997). Cadmium availability in five soil series from the Yonne district. Burgundy . France. Environmental Pollution, 95(1), 93-103. Available from: https://doi.org/10.1016/S0269-7491 (96)00078-4.

2. Arnaud, P. (1998). Chimie Physique (4th edition). (pp. 50-52). Paris: Dunod.

3. Lebourg, A. (1996). Etude de l'Extraction des Métaux en Traces de Sols Pollués en Vue de la Détermination de Leur Biodisponibilité. (p. 7). Thesis of Doctor. l'Uiversité des sciences et technologies de Lille.

4. Ghestem, J.P. (1997). Extraction par l'EDTA de Metaux Traces de Sols Pollués; Application à l'Etude de la Faisabil ité d'une Spéciation de Ces Metaux. (pp. 1-157). Thesis of Doctor. University of Paris VII - Denis DIDEROT.

5. Pinta, M., Baudin, G., Bourdon, R., Burelli, F., Condylis, A., Ecrement, F., Hocquaux, H., Kovacsik, G., Kuhn, V., L aporte, J., Normand, J., Riandey, C., Ropert, M.E., Rousselet, F., Ryser, S., Thuillier, F., Voinovitch, I. (1979). Spect rométrie d'Absorption Atomique - Applications à l'Analyse Chimique (second edition). Tome 1. (pp. 129-249). Paris: Masson O.R.S.T.O.M...

6. Bermond, A., Baize, D., Mench, M., Kim, S.A. (2014). Analyses of soil cadmium and copper contents on a Domerie $\mathrm{n}$ soil series of Burgundy in France. Afr. J. Biotechnol. 13(12), 1343-1350. Available from: https://dx.doi.org/10.589 7/ajb12.1022.

Citation: Alain Bermond et al (2021 Analyses of Soil Copper Contents on Chaponne of Carixien Soil Series of Burgundy in France. South Asian Res J Bio Appl Biosci, 3(2), 28-30. 